Universal Decimal Classification (UDC) number 614.1

\title{
HUMAN HEALTH RISK ASSESSMENT OF EXPOSURE TO EMISSIONS FROM THE KARACHAGANAK OIL AND GAS CONDENSATE FIELD ACCORDING TO CALCULATIONS AND MONITORING DATA
}

\author{
U.I. Kenesariyev ${ }^{1}$, A.T. Dosmukhametov ${ }^{1}$, \\ D.U. Kenesary ${ }^{1}$, A.F. Kenzhebaev ${ }^{2}$ \\ 1 S.D. Asfendiyarov Kazakh National Medical University, Kazakhstan, Almaty, Academic Building 2, 1 Tole bi \\ 94 St., 050012, \\ 2 The Committee of State Sanitary and Epidemiological Surveillanc of the Ministry of Public Health of the \\ Republic of Kazakhstan, The Ministries' Building, Kazakhstan, Astana, 8 Orynbor, Left Bank, 010000
}

\begin{abstract}
It is shown that priority pollutants posing hazard to public health in the zone influenced by emissions of "Karachaganak Petroleum Operating BV" Limited Liability Partnership (TOO) at the Karachaganak oil and gas condensate field (KOGCF) are nitrogen dioxide and oxide, sulfur dioxide and hydrogen sulfide. It is found that hazard indexes for the most affected critical organ system (respiratory) calculated for the population living near the borders of the sanitary protection zone of the object, did not exceed 1.0 both for short- and long-term exposure, which indicated an acceptable risk level. By chronic exposure, hazard indexes for different directions from the industrial area were more than by $50 \%$ influenced by levels of nitrogen dioxide and sulfur dioxide, while the risks of acute exposure are mainly determined by exposure to hydrogen sulfide. The data obtained can be used in organization of sanitary protection zone of a plant, conservation measures planning, including industrial ambient air quality control in the zone influenced by emissions from the plant.
\end{abstract}

Key words: industrial emissions, sanitary protection zone, risk assessment, non-carcinogenic and carcinogenic risks.

Safe conditions of living in the areas adjacent to large industrial complexes being the sources of negative impact on the environment and human health, are traditionally provided by organization of sanitary protection zones $[1,2,4,5]$.

In the context of the sanitary legislation requirements, the dimensions of a sanitary protection zone are established in accordance with the sanitary classification of plants and depend on plant's capacity, operating conditions, nature of the object and the amount of emitted pollutants. The newly approved "Sanitary regulations on the establishment of sanitary protection zone of production facilities" Sanitary regulations No. 93 of 17.01.2012, state that the substantiation of a sanitary protection zone for industrial facilities of I and II hazard classes requires assessment of health risk posed to the population living near an industrial facility. [9] However, it should be noted that the risk

(C) Kenesariyev U.I., Dosmukhametov A.T., Kenesary D.U., Kenzhebaev A.F., 2013

Kenesariyev Usen Ismailovich - DSc in Medicine, Head of the Department of General Hygiene and Ecology (e-mail: kenesary@inbox.ru, tel.: 8 (727) 292-67-22).

Dosmukhametov Askhat Tursynkhanovich - PhD in Medicine, Docent of the Department of General Hygiene and Ecology, Leading Researcher (e-mail: zhantore_2009@mail.ru, tel.: 8 (727) 292-67-22).

Kenesary Dinara Usenovna - PhD Student in Public Health, MA in Public Health (e-mail: dku999@mail.ru, tel.: 8 (727) 292-67-22).

Kenzhebaev Amirkhan Fazylovich - Expert (e-mail: a.kenzhebaev@mz.gov.kz, tel.: 8 (701) 657-77-93). 
assessment methodology is not yet used completely enough for practical purposes by organizations of the Republic of Kazakhstan, despite the fact that the implementation of these approaches is recommended by the World Health Organization and other major international organizations (United Nations Environment Program (UNEP), International Labor organization (ILO), Organization for Economic Cooperation and Development (OECD), etc.) and is extensively tested in designing of sanitary protection zones in the Russian Federation $[3,5,7,8]$.

The purpose of research is the comparative assessment of health risk posed by population exposure to pollutants, according to calculated data at the designing stage and instrumental measurements at the stage of commissioning with the actual capacity of the industrial complex of "Karachaganak Petroleum Operating BV" Limited Liability Partnership (TOO) plants at the Karachaganak field (Karachaganak oil and gas condensate field (KOGCF)).

Materials and methods. Assessment of risk to human health based on modelling and instrumental measurements of air quality was carried out by the classical scheme, comprising four stages: hazard identification, exposure assessment, assessment of "dose-effect" relationship and risk characterization.

Design modelling was performed using the software package "ERA risks," applying the data of the " Project of norms of maximum permissible emissions for the Karachaganak oil and gas condensate field (KOGCF) for 2011-2015", developed in accordance with the introduction of a new production line in the plant complex "Karachaganak Petroleum Operating BV" Limited Liability Partnership (TOO).

Instrumental studies included annual continuous measurements at the environmental monitoring station.

Assessment of ground-level concentrations were performed in eight representative points located at the 8 rhumbs of the wind rose around the perimeter of the field on the boundary of the target sanitary protection zone of the Karachaganak oil and gas condensate field (KOGCF) at a distance of 3000 to 5000 meters from the extreme emission sources. At these points environmental monitoring stations are located (environmental monitoring stations 005-012), at which field measurements of the air quality were carried out.

Quantitative assessment of risk of non-carcinogenic effects was carried out in accordance with the "Guidelines... " [6 ], using the criteria for acute and chronic exposure and comparing hazard coefficients and indexes with 1.0. If hazard coefficient (index) was equal to or less than 1.0, the risk of adverse effects was considered negligible, and if it was above 1.0 the risk was considered unacceptable.

Results and discussion. According to the inventory statements for emission sources of 
the "Karachaganak Petroleum Operating BV" Limited Liability Partnership (TOO) at the design stage it was identified, that more than 50 chemicals with a total mass of 17920 tons/year are emitted in the ambient air. Taking into account the criteria for selection of substances to be included in the risk assessment, some chemical compounds were excluded from the list to be considered. Thus, in total 16 pollutants had emissions of less than $0.007 \%$, and 14 substances had concentrations significantly lower than reference levels (hazard coefficient $H Q<0.1$ ), individual cancer risk for seven substances was less than $10^{-6}$. For 11 substances there were no adequate data on their biological action, which precluded the risk assessment or provisional prognosis in terms of toxicity and hazard to the body.

Thus, a priority list of chemicals forming $85 \%$ of the project weight of total emissions and are potentially dangerous in such amounts for public health, included four components: sulfur dioxide, nitrogen dioxide, nitrogen oxide, carbon monoxide (Table 1).

As seen from the data provided, among the priority substances, the highest relative hazard index was obtained for sulfur dioxide, and relatively lower hazard index - for carbon monoxide.

At automated stations (environmental monitoring stations) after commissioning of a new production line at full capacity, the monitoring was carried out for four priority components and additionally - for hydrogen sulfide as a pollutant specific for the studied production.

It should be noted that during the operation of the facility the real (actually determined) emissions were found to be $10-50 \%$ lower than those included in the project documentation for different substances, that suggested the high technological discipline in the plant (Table 2).

Table 1

\section{Priority pollutants in the emissions of "Karachaganak Petroleum Operating BV" plants according to the project documentation}

\begin{tabular}{|c|c|c|c|c|c|c|c|}
\hline Code & Substance & CAS & $\begin{array}{c}\text { Total } \\
\text { emission, } \\
\text { tonnes/year }\end{array}$ & $\begin{array}{c}\text { Reference } \\
\text { concentration } \\
\text { for acute } \\
\text { exposures, } \\
\mathrm{mg} / \mathrm{m} 3\end{array}$ & $\begin{array}{c}\text { Reference } \\
\text { concentration for } \\
\text { chronic } \\
\text { exposures, } \\
\mathrm{mg} / \mathrm{m} 3\end{array}$ & $\begin{array}{c}\text { Hazard risk } \\
\text { index, HRI }\end{array}$ & $\begin{array}{c}\text { Rank for } \\
\text { non- } \\
\text { carcinogen } \\
\text { ic effect }\end{array}$ \\
\hline 0330 & sulfur dioxide & $7446-09-5$ & 9857,43 & 0,05 & 0,05 & 985742,5 & 1 \\
\hline 0301 & nitrogen dioxide & $10102-44-0$ & 2340,84 & 0,04 & 0,04 & 234084,1 & 2 \\
\hline 0304 & nitrogen oxide & $10102-43-9$ & 403,2 & 0,06 & 0,06 & 40319,97 & 3 \\
\hline 0337 & carbon monoxide & $630-08-0$ & 3070,0 & 3,0 & 3,0 & 3070,01 & 4 \\
\hline
\end{tabular}

In general, the data about air emissions which took place confirmed the correctness of selection of priority substances for carrying out field studies and health risk assessment.

Table 3 shows the summarized results of the measurements performed at monitoring 
sites, which were subsequently used in the assessment of real population exposure 1.

As seen from Table 3, practically everywhere the ground-level concentrations of chemical pollutants obtained with instrumental studies were higher than those determined by dispersion calculations, however, spatial patterns remained unchanged (Figure 1).

The resulting mismatch can be due to high background levels of pollution, which were not taken into account in the modelling. In general, the correspondence between calculated and field data, when determining the short-term pollution levels, was significantly higher than when determining the annual average concentrations.

Hazard index values according to calculated and field data for chronic and acute exposures in regard to respiratory organs, in the area of the target sanitary protection zone the Karachaganak oil and gas condensate field (KOGCF) after commissioning of the 4th production line, are shown in Table 4.

The data obtained suggest that there is no unacceptable risk at the border of the sanitary protection zone of the object. The highest values of hazard index in regard to respiratory organs were obtained when calculating chronic risk and reached 0.77-0.79 in the northern, northwestern and western directions with respect to the industrial site. However, in general, risk levels for different rhumbs of the wind rose around the facility were similar.

Hazard indexes for acute exposure ranged from 0.32 to 0.39 according to the calculations of dispersion, and from 0.37 to 0.61 according to instrumental measurements. Concerning other organs and systems, hazard indexes were significantly lower and the risk was also qualified as acceptable.

The structure of hazard indexes in acute and chronic exposures in regard to respiratory system differed significantly. While by chronic exposures hazard indexes for different directions from the industrial area were more than by $50 \%$ influenced by nitrogen dioxide and sulfur dioxide levels, the risks by acute exposures were almost always determined by the exposure to hydrogen sulfide (Figure 2).

\footnotetext{
${ }^{1}$ Data on carbon monoxide are not shown, since the hazard coefficient for the substance did not exceed 0.1 of the reference level, and thereafter the authors only assessed the risks associated with respiratory diseases, the incidence of which is not influenced by carbon monoxide.
} 
Table 2

Comparative figures for total emissions for the design capacity and actual capacity of “Karachaganak Petroleum Operating B.V." Limited Liability Partnership (TOO) facilities

\begin{tabular}{|l|c|c|}
\hline \multicolumn{1}{|c|}{ Substance } & $\begin{array}{c}\text { Actual total amount of emissions for } \\
\text { 2012, tonnes/year }\end{array}$ & $\begin{array}{c}\text { Percent from total projected } \\
\text { emission level, \% }\end{array}$ \\
\hline sulfur dioxide & 4956.47 & 50.28 \\
\hline nitrogen dioxide & 1672.97 & 71.47 \\
\hline nitric oxide & 282.48 & 70.06 \\
\hline carbon monoxide & 1461.79 & 47.62 \\
\hline hydrogen sulfide & 28.55 & 89.60 \\
\hline
\end{tabular}

Table 3

Calculated data and results of instrumental measurements of ground-level concentrations of chemical pollutants on the border of the sanitary protection zone "Karachaganak Petroleum Operating B.V." Limited Liability Partnership (TOO) (mg/m³)

\begin{tabular}{|l|l|l|l|l|l|l|l|c|}
\hline \multirow{2}{*}{ Sampling point } & nitrogen dioxide & \multicolumn{2}{|c|}{ sulfur dioxide } & \multicolumn{2}{|c|}{ nitric oxide } & $\begin{array}{c}\text { hydrogen } \\
\text { sulfide }\end{array}$ \\
\cline { 2 - 8 } & actual & calculated & actual & calculated & actual & calculated & actual \\
\hline \multicolumn{2}{|c|}{ Annual concentration, 95\% upper confidence bound of the range } & 0.001 \\
\hline $\begin{array}{l}\text { East sanitary protection zone } \\
\text { (environmental monitoring } \\
\text { station 005) }\end{array}$ & 0.002 & 0.0008 & 0.004 & 0.00225 & 0.006 & 0.00004 & 0.001 \\
\hline $\begin{array}{l}\text { Northeast sanitary protection } \\
\text { zone (environmental } \\
\text { monitoring station 006) }\end{array}$ & 0.002 & 0.0004 & 0.004 & 0.003 & 0.006 & 0.00005 & 0.001 \\
\hline $\begin{array}{l}\text { North sanitary protection } \\
\text { zone (environmental } \\
\text { monitoring station 007) }\end{array}$ & 0.003 & 0.0004 & 0.007 & 0.0035 & 0.0042 & 0.00006 & 0.001 \\
\hline $\begin{array}{l}\text { Northwest sanitary protection } \\
\text { zone (environmental } \\
\text { monitoring station 008) }\end{array}$ & 0.003 & 0.0002 & 0.006 & 0.0025 & 0.0042 & 0.00006 & 0.001 \\
\hline $\begin{array}{l}\text { West sanitary protection zon } \\
\text { (environmental monitoring } \\
\text { station 009) }\end{array}$ & 0.004 & 0.0004 & 0.005 & 0.002 & 0.0042 & 0.00005 & 0.001 \\
\hline $\begin{array}{l}\text { Southwest sanitary protection } \\
\text { zone (environmental } \\
\text { monitoring station 010) }\end{array}$ & 0.003 & 0.00034 & 0.004 & 0.00225 & 0.006 & 0.00004 & 0.001 \\
\hline $\begin{array}{l}\text { South sanitary protection } \\
\text { zone (environmental } \\
\text { monitoring station 011) }\end{array}$ & 0.002 & 0.0004 & 0.005 & 0.0025 & 0.0042 & 0.00039 & 0.001 \\
\hline $\begin{array}{l}\text { Southeast sanitary protection } \\
\text { zone (environmental } \\
\text { monitoring station 012) }\end{array}$ & 0.004 & 0.00032 & 0.004 & 0.0025 & 0.0042 & 0.00004 & 0.001 \\
\hline $\begin{array}{l}\text { East sanitary protection zone } \\
\text { (environmental monitoring } \\
\text { station 005) }\end{array}$ & 0.01 & 0.004 & 0.004 & 0.00225 & 0.0288 & 0.0576 & 0.001 \\
\hline $\begin{array}{l}\text { Northeast sanitary protection } \\
\text { zone (environmental } \\
\text { monitoring station 006) }\end{array}$ & 0.01 & 0.002 & 0.004 & 0.003 & 0.0288 & 0.0504 & 0.001 \\
\hline
\end{tabular}


Risk assessment practice

\begin{tabular}{|l|l|l|l|l|l|l|l|}
\hline $\begin{array}{l}\text { (environmental monitoring } \\
\text { station 007) }\end{array}$ & 0.015 & 0.002 & 0.007 & 0.0035 & 0.0792 & 0.0504 & 0.001 \\
\hline $\begin{array}{l}\text { Northwest sanitary protection } \\
\text { zone (environmental } \\
\text { monitoring station 008) }\end{array}$ & 0.015 & 0.001 & 0.006 & 0.0025 & 0.072 & 0.0576 & 0.001 \\
\hline $\begin{array}{l}\text { West sanitary protection zone } \\
\text { (environmental monitoring } \\
\text { station 009) }\end{array}$ & 0.02 & 0.002 & 0.005 & 0.002 & 0.0216 & 0.0576 & 0.001 \\
\hline $\begin{array}{l}\text { Southwest sanitary protection } \\
\text { zone (environmental } \\
\text { monitoring station 010) }\end{array}$ & 0.015 & 0.0017 & 0.004 & 0.00225 & 0.0288 & 0.0576 & 0.001 \\
\hline $\begin{array}{l}\text { South sanitary protection } \\
\text { zone (environmental } \\
\text { monitoring station 011) }\end{array}$ & 0.01 & 0.002 & 0.005 & 0.0025 & 0.0288 & 0.0504 & 0.001 \\
\hline $\begin{array}{l}\text { Southeast sanitary protection } \\
\text { zone (environmental } \\
\text { monitoring station 012) }\end{array}$ & 0.02 & 0.0016 & 0.004 & 0.0025 & 0.0288 & 0.0504 & 0.001 \\
\hline
\end{tabular}

North sanitary protection zone

North sanitary protection zone

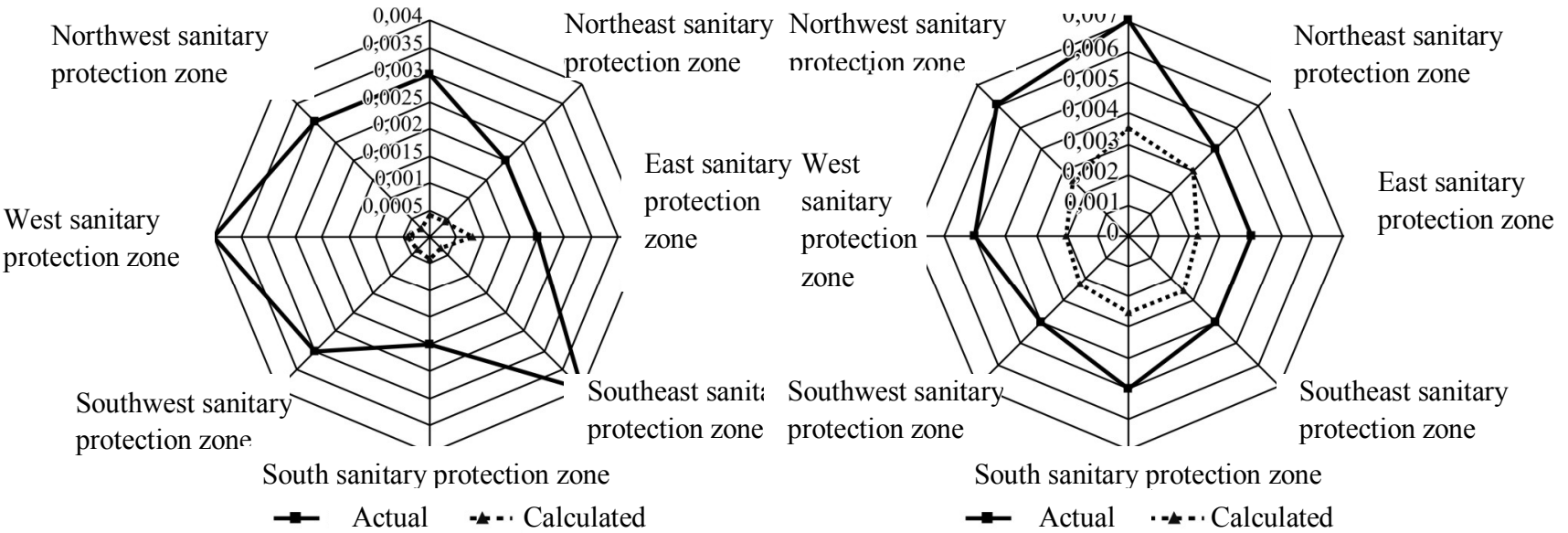

Figure 1. Distribution of average annual concentrations of nitrogen dioxide (a) and sulfur dioxide (b) according to the wind rose rhumbs 
Table 4

\section{Hazard indexes for disorders of respiratory organs in the population living near the borders of a sanitary protection zone (according to the data of dispersion calculations and instrumental measurements)}

\begin{tabular}{|l|c|c|c|c|}
\hline \multirow{2}{*}{$\begin{array}{l}\text { Names of fixed monitoring } \\
\text { points }\end{array}$} & \multicolumn{2}{|c|}{$\begin{array}{c}\text { Hazard index } \\
\text { for chronic exposures (HI) }\end{array}$} & \multicolumn{2}{c|}{$\begin{array}{c}\text { Hazard index } \\
\text { For acute exposures }\end{array}$} \\
\cline { 2 - 5 } & $\begin{array}{c}\text { According to } \\
\text { measurements }\end{array}$ & $\begin{array}{c}\text { According to } \\
\text { calculations (withoutmeasurements }\end{array}$ & $\begin{array}{c}\text { According to } \\
\text { calculations (without }\end{array}$ & 0,39 \\
\hline $\begin{array}{l}\text { East sanitary protection zone } \\
\text { (environmental monitoring } \\
\text { station 005) }\end{array}$ & 0,73 & 0,07 & 0,43 & 0,33 \\
\hline $\begin{array}{l}\text { Northeast sanitary protection } \\
\text { zone (environmental } \\
\text { monitoring station 006) }\end{array}$ & 0,73 & 0,07 & 0,45 & 0,35 \\
\hline $\begin{array}{l}\text { North sanitary protection } \\
\text { zone (environmental } \\
\text { monitoring station 007) }\end{array}$ & 0,79 & 0,08 & 0,55 & 0,32 \\
\hline $\begin{array}{l}\text { Northwest sanitary protection } \\
\text { zone (environmental } \\
\text { monitoring station 008) }\end{array}$ & 0,77 & 0,06 & 0,49 & 0,34 \\
\hline $\begin{array}{l}\text { West sanitary protection zone } \\
\text { (environmental monitoring } \\
\text { station 009) }\end{array}$ & 0,77 & 0,05 & 0,37 & 0,36 \\
\hline $\begin{array}{l}\text { Southwest sanitary protection } \\
\text { zone (environmental } \\
\text { monitoring station 010) }\end{array}$ & 0,76 & 0,05 & 0,61 & 0,37 \\
\hline $\begin{array}{l}\text { South sanitary protection } \\
\text { zone (environmental } \\
\text { monitoring station 011) }\end{array}$ & 0,72 & 0,07 & 0,06 & 0,36 \\
\hline $\begin{array}{l}\text { Southeast sanitary protection } \\
\text { zone (environmental } \\
\text { monitoring station 012) }\end{array}$ & 0,75 & 58 & 0,38 \\
\hline
\end{tabular}

Note: at the planning sage no calculations of hazard coefficients for hydrogen sulfide were not conducted since it was excluded from the list of analytes.

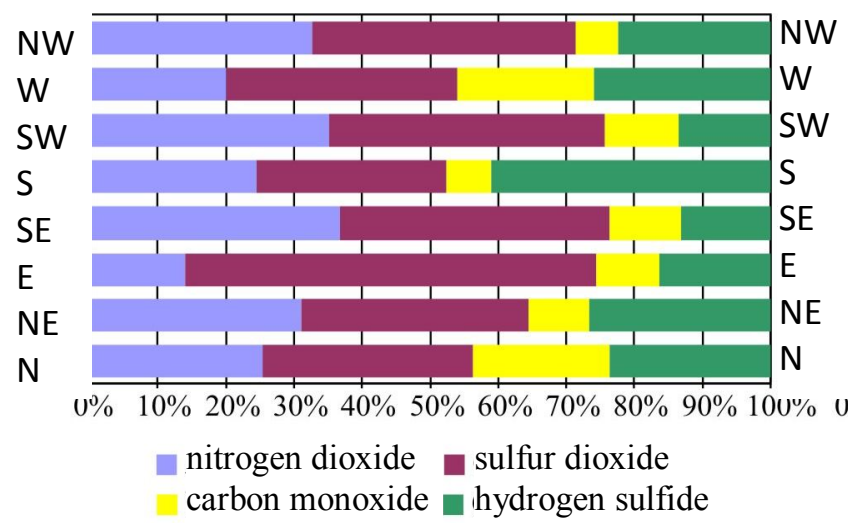

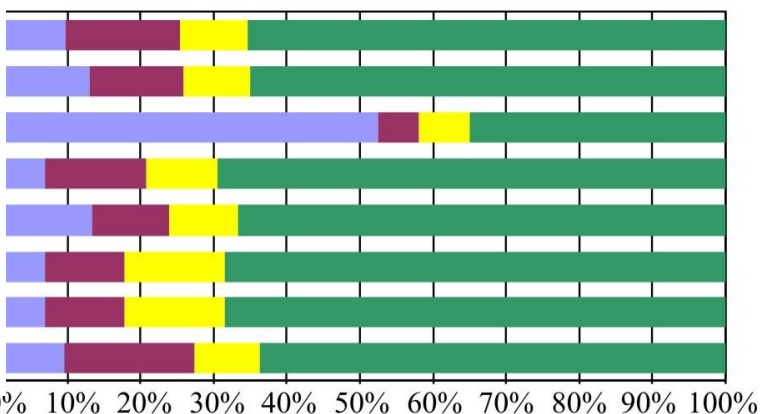

nitrogen dioxide $\square$ (sulfur dioxide

carbon monoxide $\square$ (hydrogen sulfide

$\mathrm{b}$

Figure 2. Contribution of the individual pollutants in formation of hazard indexes by chronic (a) and acute (b) exposure to plant's emissions (according to rhumbs of the wind rose) 
It is advisable to take into account the obtained results when deciding on the location of additional sources of emissions of nitrogen dioxide, sulfur and hydrogen sulfide at the plant.

Thus, the following conclusions can be made:

- The priority pollutants, which constitute a hazard to public health in the area of influence of emissions from "Karachaganak Petroleum Operating BV" Limited Liability Partnership (TOO) at the Karachaganak oil and gas condensate field (KOGCF), are nitrogen dioxide and nitrogen oxide, sulfur dioxide and hydrogen sulfide;

- The results of instrumental measurements generally demonstrate higher levels of ground-level concentrations of the chemicals studied, in comparison with the calculated values, therefore health risk assessment was performed using both model and field data;

- Hazard indexes for the most critically affected system (respiratory organs), calculated for the population living near the boundaries of the sanitary protection zone of the object, did not exceed 1.0 both by short and long-term exposure, indicating an acceptable risk level;

- By chronic exposures, hazard indexes in different directions from the industrial area were more than by $50 \%$ influenced by nitrogen dioxide and sulfur dioxide levels, while the risks of acute exposure were mainly determined by the exposure to hydrogen sulfide;

- The data obtained may be used for organization of sanitary protection zone, conservation measures planning, including performing industrial quality control of ambient air in the zone affected by emissions from the plant.

\section{References}

1. Avaliani S.L., Revich B.A., Balter B.M. Ocenka riska zagrjaznenija okruzhajushhej sredy dlja zdorov'ja naselenija kak instrument municipal'nojj ekologicheskoj politiki v Moskovskoj oblasti [Health risk assessment of environmental pollution as a tool of municipal environmental policy in the Moscow Region]. Podol'sk: Biblioteka «Ezhednevnye novosti. Podmoskov'e», 2010.311 p.

2. Mishina A.L. Ispol'zovanie metodologii ocenki riska dlja upravlenija kachestvom atmosfernogo vozduha [Using the risk assessment methodology for ambient air quality management]. Zdorov'e naselenija $i$ sreda obitanija, 2009, no. 6, pp. 26-29.

3. Kapustin V.M., Jarmuhametov A.S., Muhametshin I.F., Maj I.V., Gil'denskiol'd R.S Opyt kompleksnogo reshenija voprosov jekologicheskoj bezopasnosti i obespechenija sanitarno-gigienicheskih trebovanij pri razrabotke proektov sanitarno-zashhitnyh zon dlja dejstvujushhih i proektiruemyh predprijatij Rossii (v tom chisel respubliki Tatarstan) [An experience of a comprehensive solution of ecological safety issues and of ensuring health and environmental hygiene requirements in the development of buffer zone projects for the operating companies and those under construction in Russia (including the Republic of Tatarstan)]. Teoreticheskie $i$ prikladnye problemy servisa, 2010, no. 3 (36), pp. 7-19.

4. Pinigin M.A., Antipova N.D., Zabroda N.N. Priemlemyj risk zdorov'ju kak kriterij ustanovlenija razmera sanitarno-zashhitnyh zon [Acceptable health risk as a criterion for buffer zone size]. Sistemnyj analiz $i$ upravlenie $v$ biomedicinskih sistemah, 2011, vol. 10, no. 2, pp. 439-443.

5. Boev V.M., Kireev A.A., Osijan S.A., Karpenko I.L., Boev V.V. Prakticheskoe primenenie metodologii ocenki ajerogennogo riska dlja zdorov'ja naselenija pri obosnovanii sanitarno-zashhitnoj zony [Practical application of the airborne health risk assessment methodology in the substantiation of buffer zones]. Gigiena i sanitarija, 
2009, no. 4, pp. 82-83.

6. Rukovodstvo poocenke riska dlja zdorov'ja naselenija pri vozdejstvii himicheskih veshhestv, zagrjaznjajushhih okruzhajushhuju sredu (R 2.1.10.1920-04) [Guidelines for health risk assessment of exposure to chemical substances polluting the environment ( $\mathrm{R}$ 2.1.10.1920-04)]. Utverzhdeno Glavnym gosudarstvennym sanitarnym vrachom Rossijskoj Federacii 05.03.2004.Available http://www.gosthelp.ru/text/R2110192004Rukovodstvopoo.html.

7. Fokin S.G., Avaliani S.L., Bushtueva K.A., Bespal'ko L.E., Andrianova M.M., Bobkova T.E., Balter B.M., Safonov G.V., Razrabotka upravlencheskih reshenij v celjah obespechenija bezopasnosti dlja zdorov'ja naselenija $\mathrm{V}$ zone vlijanija vybrosov krupnyh promyshlennyh kompleksov [The development of management decisions to ensure human health safety in the area influenced by the emissions from large industrial complexes]. Gigiena $i$ sanitarija, Moscow, 2006, no. 1, pp. 40-42.

8. Fokin S.G., Juan' A.Ch., Bespal'ko L.E., Bobkova T.E., Prjadko A.L. Sanitarno-zashhitnyezony i sanitarnajaklassifikacijapredprijatij, sooruzhenij i inyhob\#ektov.Vremennyemetod.rek. poprimeneniju trebovanij SanPiN 2.2.1/2.1.1200-03 [Buffer zones and health classification of industrial companies, facilities and other works. Temporary methodical guidelines for using SanPin 2.2.1/2.1.1200-03 requirements]. Moscow: Federal'nyj centr gossanjepidnadzora Minzdrava Rossii, 2004. 28 p.

9. Sanitarnye pravila «Sanitarno-jepidemiologicheskietrebovanija k zdanijam i sooruzhenijam proizvodstvennogo naznachenija» i «Sanitarno-jepidemiologicheskie trebovanija po ustanovleniju sanitarnozashhitnoj zony proizvodstvennyh ob\#ektov» [Health regulations «Health and epidemiological requirements for industrial (manufacturing) buildings and facilities» and «Health and epidemiological requirements to the establishment of buffer zones for manufacturing facilities»)]. Utverzhdeno postanovleniem Pravitel'stva RK No.93 ot 17.01.12. Available at: http://www.pandia.ru/text/77/195/40018.php. 